\title{
Ethical Life in Kierkegaard and Williams
}

\section{Barry Stocker}

\begin{abstract}
A discussion of how the criticisms of ethical theory in Søren Kierkegaard and Bernard Williams both reinforce each other and also provide some challenges to each other. Despite Williams' brief and dismissive encounter with Kierkegaard around the reading of a ancient tragedy, both oppose any tendency to see the characters in those tragedies as lacking in agency. Both are consistently concerned with how the individual struggles for some ethical agency and how no individual can be free of the influence of chance or error. Kierkegaard and Willliams are shown to both oppose relativism and communitarianism in ethics, along with utilitarianism and to both have an interest in plurality of ethical ideas of how to live.
\end{abstract}

Keywords: Individuality, agency, tragedy, communal, luck

Williams presents his position in Ethics and the Limits of Philosophy (1993a) as that of a return to Greek and antique ethics. This can be seen in the opening of the book with 'Socrates' Question' and a variety of other suggestions that the Greek tradition offers more than moral theories developed since the rise of Christianity (e.g. 30-34,198). Williams' antique Greek orientation is taken further in Shame and Necessity (1993b). The Greek tradition can be taken to base ethics on some idea of the ends of the human individual, or what is naturally good for that individual, promoting happiness and the good life, which is what Williams explores. Williams suggests some moderation of the ancient Greek tendency to base ethics on absolutely defined natural desires in chapter three of Ethics and the Limits of Philosophy, 'Foundations: Well-Being'.

The view of Greek ethics he outlines was anticipated by David Hume in An Enquiry Concerning the Principles of Morals, where Hume argues that ancient philosophy presents an ethics more directed towards human aversions and attractions thane ethical theory since, so more concerned with the nature of humans than later theory, though it also tends to present itself as a form of absolute rationalism: 'The ancient philosophers though they often affirm, that virtue is nothing but conformity to reason, yet, in general, seem to consider morals as deriving their existence from taste and sentiment' $(1975,170)$. In part, Williams can be seen as following 68-82 
up on that without following Hume in all aspects of his model of mind, perception, and knowledge. The more social and historical aspects of Hume find many resonances in Williams.

This way of thinking about ethics explored in various philosophers: in Williams' own time e.g. the later work of Michel Foucault, before Williams e.g. Friedrich Nietzsche, before Hume e.g. Michel de Montaigne. It is Søren Kierkegaard who is considered here with regard to ways in which he is much more concerned with performative subjectivity, and style in writing, as ways of dealing with the experimental, variable, and individualistic aspects of ethics than Williams, while pursuing an overlapping project.

Kierkegaard's scepticism about ethical theory is driven by a religious orientation lacking in Williams. However, Kierkegaard does not attempt to ground ethics in theological metaphysics, but rather challenges ethical system, such as the Aristotelian, Kantian, and Hegelian, from the position of the self as a truly individual self, in various ways which include his more indirect attempts to dive the reader towards a properly religious point of view with regard to ethics as in Fear and Trembling (1983) and his more direct exposition of Christian ethics as in Works of Love (1995). The self as discussed by Kierkegaard, most clearly and extensively explained in The Concept of Anxiety (1980) and Concluding Unscientific Postscript (1992) grasps itself as unified over time, as more than a set of moments of experience, but not as an unchanging thing. Though in terms of historical location, Kierkegaard could have been concerned with evaluating utilitarian ethical system, he does not focus any attention on it. Anyway, it is clear that ethical theories of utility are remote from Kierkegaard's goals, so much so that there is no equivalent of Williams' long running contestation of its influence in Anglophone philosophy going back to last chapter of Morality: An Introduction to Ethics (1972).

Kierkegaard's obvious goal is to promote the integrity of the self. The idea of a self isolated from all possible ethical blame and failure is one of Williams' targets of criticism, particularly in the essays that make up Moral Luck (1981), but this is not what Kierkegaard is concerned with in his emphasis on individual integrity. The integrity proposed is that arising from awareness that the self is more than a series of moments and experiences, though never able to achieve the kind of pure transcending self in this life which might pertain to God or the self after death. Kierkegaard discusses the self as it is capable of ethical and religious concern, not as immune from error and external influences. Kierkegaard's writing, even when it is more 'direct' and 'religious' rather than 
'indirect' and 'aesthetic' is concerned with the experience of something transcending the momentary in experience rather than the metaphysics of the transcendental self or absolute moral obligations. The absolute has an important role in Kierkegaard, but that is with regard to the structure of experience and self-relation not metaphysical entities or obligations on the individual. Kierkegaard's ethics is generated by what it means to be a functioning responsible individual who is capable of faith, a relation with absolute; it is not generated from a purely theological standpoint and does not rely much on Christian theology. It is in these ways that it does not rely on the kind of very pure personal integrity that Williams criticises as a moral requirement.

Kierkegaard is concerned with the point of view of the self as it copes with living, including anxiety, love, and, and humour. Williams consistent use of clear and literal, if demanding, academic prose is certainty in contrast to Kierkegaard, whose strategies and styles of writing are means to shake readers out of their assumptions about ethics and morality, as well as other matters. Williams' ethical approaches can nevertheless be illuminated by comparison with Kierkegaard for at least two reasons, other than the common project of a return to the kind of ethics undertaken by the ancient Greeks defined above through Hume: Williams puts the discussion of literature at the centre of ethical writing in Shame and Necessity (1993b), where he is discussing Greek classics well known to Kierkegaard; Williams' concerns with pluralism, practice, and experimentation in ethics lend themselves to concern with how forms of writing might be part of that, even if Williams himself maintains a style of writing and of argument which does not draw attention to itself. The attention to literary texts and the importance of literature for ethics in Williams is itself a way of dealing with the questions of style and strategy without himself equalling the widely acknowledged literary capacities of Kierkegaard, as great as any major novelist.

The relation between ethical investigation and literature, which is fundamental to William's work, is something that can be taken up in various ways that bring in Kierkegaard. The ideal starting point is maybe Williams' comment on Kierkegaard as reader of tragedy in Shame and Necessity (1993b), brief as it is. This is in Chapter Six 'Freedom, Possibility, and Power' in a discussion of Agamemnon in Aeschylus' play of that name, with regard to the decision of the King of Argos to sacrifice his daughter Iphigenia to the goddess Artemis and thereby enable the favourable winds necessary for the Greek fleet sail to Troy. 
A major difficulty in understanding the passage from the Agamemnon has been ethical: the critics could not understand how someone might not have to choose between two courses of action both of which involved a grave wrong, so that whatever he does will be bad, and whatever he does, he will suffer what, in discussing responsibility, I call an agent's regret at what he has done. The ethical question in such a case is not soluble without remainder, and Kierkegaard was wrong, not in saying merely that the tragic hero "stays within the ethical" - that much is true-but in supposing that there is an unambiguous ethical answer. "The tragic hero gives up what is certain for what is still more certain", Kierkegaard said, and this is not right, at least in the case of Aeschylus' Agamemnon (Kierkegaard had an Agamemnon in mind, but he was Euripides'.) (Williams 1993b, 134).

It is in a sense true, as Kierkegaard says, "that the eye of the beholder rest confidently upon" the tragic hero, but that is not because of ethical certainty, but because the spectator is given the confidence of a tragic representation (something that is often not given, in fact, by Euripides). Kierkegaard was contrasting the tragic hero with indeed a different figure, Abraham, whose willingness to proceed against the ethical is not mediated by the ethical at all but proceeds "on the strength of the absurd." Such a relationship to the divine is unknown to paganism": that, for sure, is true. (Williams 1993b, 208).

Williams' suggestion that Kierkegaard's account of Agamemnon might be different from his, because it refers to Euripides' Iphigenia in Aulis rather than Aeschylus' Agamemnon is hard to understand, since both plays allow for a critical attitude towards the sacrifice, and suggest some uncertainty in Agamemnon's mind about it. Both tend to suggest that we should criticise the sacrifice as unnecessary violence to serve Agamemnon's pride and ambition, with regard to a war that should not have taken place, and both suggest that such a reaction existed amongst the Greeks.

Williams' implied opinion about the difference between Euripides' Agamemnon and Sophocles' Agamemnon may be questionable, but does not in itself lead to a questioning of Williams' criticism of Kierkegaard, which is that Kierkegaard was failing to note uncertainty in the mind of the tragic hero faced with an ethical dilemma. However, Williams 
did misjudge Kierkegaard's approach to tragedy and ethics. Given that his discussion of Kierkegaard's position is so brief and only refers to Kierkegaard's most widely read book, Fear and Trembling (1983), this is not surprising. Williams does not mention, and is possibly unaware, that Kierkegaard addressed tragedy at greater length in Either/Or (1987) Part One, 'The Tragic in Ancient Drama Reflected in the Tragic in Modern Drama'. Looking at the quoted passage from Fear and Trembling (1983), Problema I in isolation, as Williams did, made it more likely that he would attribute to Kierkegaard the view that in ancient tragedy a higher ethical purpose serving the state, or nation, overrides a lower more individual ethical purpose without any ambiguity. If Kierkegaard was saying such a thing it would be a highly implausible position, which would leave it unexplained why there is conflict of points of view in ancient tragedy and direct expressions of uncertainty.

The tragedy that Kierkegaard pays most attention to is Sophocles' Antigone, which is certainly the tragedy where the modern reader is most likely to look for criticism of the higher purposes of the state at work, and the character of Antigone has even become a symbol of heroic defiance of state authority. It is doubtful that ancient Greeks would have taken the play in that way, so making a straightforward hero of liberty out of Antigone, but it is a play strongly suggesting that the ancient Greeks had some interest in tensions around differing conceptions of law, right, justice, and authority in enforcing laws. Kierkegaard was certainly aware of Hegel's brief but famous and influential commentary on Antigone in the Phenomenology of Spirit (1977, 261-262, 284-289), which suggest the play represents a breakdown of previous Greek beliefs in the unity and continuity of state law with divine law. As with the more political appropriations of Antigone in Bonnie Honig (2008, 2009, 2010, 2011) and Judith Butler (2000), there is some element, in Hegel's reading, of projection of the concerns of the writer's own time onto the world of classical era Greece, but when thinking about Kierkegaard's attitude to ancient tragedy it is important to acknowledge how much importance he gave to a play that had already become a symbol of Greek questioning of their own ethical world, even if that questioning was not quite what Hegel was reading into it.

The other major aspect of Williams' account of Kierkegaard, which is to be found in the footnote quoted, is a distrust of his religious perspective. It is a very brief remark, but the dismissive tone Williams take towards the role of religion in Kierkegaard's ethics is clear. Kierkegaard cuts across a 
Christian theological obligation-ancient life ethics distinction though. He is supportive himself of the idea that the philosopher and ethicist should be like the ancient practitioners of ethics through life (1983, 7). He does not engage in much discussion of medieval theological-metaphysical ethics, or even theological ethics since the Middle Ages. This particularly evident in The Concept of Anxiety (1980), which argues for an ethics of 'dogma' (faith), transcendence and repetition rather than immanence and recollection. That distinction is referred to the idea of metaphysics as first philosophy in Aristotle, which included theology, and Kierkegaard's suggestion that the questions of theology be separated out from metaphysics, so becoming an area of subjectivity and faith $(1980,20-21)$. The argument is for understanding hereditary, or original, sin through anxiety, psychology and the individual. It picks up on the secularised understanding of evil in Kant's Religion within the boundaries of mere reason (1996) and Schelling's Philosophical Inquiries into the Essence of Human Freedom (2006). Kierkegaard is arguing for something more 'faith' based, but not faith as arbitrary dogma, but rather of issues of faith as intertwined with issues of subjectivity overcoming anxiety, which provides the appropriate bridge between philosophy and his more Bible based Christian faith texts.

For Kierkegaard, there is something lacking in Greek tragedy that is to be found in Hebrew scripture, something above acceptance of social mores, the kind of ethics embedded in communal life that structures Agamemnon's reactions to the wish of Artemis for the sacrifice of his daughter. Part of this is for Kierkegaard, maybe, just the reassertion of a divine command authority strand in Christian thinking, what is taken up now in arguments for theological voluntarism or divine command morality (Quinn 1998, Evans 2004), though not all Kierkegaard commentators believe he is divine command theorist (Manis 2009). Anyway, while Kierkegaard does hold so some form of divine command thinking, this is not the full story or even the most significant component of Kierkegaard's general argument which is more about how to be the kind of individual who can differentiate between worldly ethics and transcendence.

Overall the argument is that the self can only avoid fragmentation between moments of subjective experience through an integration which recognises something absolute about the self as it exists over time and not just as a series of moments. Ethical rules lack application to the self, because they are universal commands, even if only universal within a defined community, in relation to the particularity of the Individual Self, den Enkelte, a recurrent reference in Kierkegaard, which has no reason to 
obey them. Kierkegaard is in line with Williams in recognising that there is no 'moral obligation' or 'moral institution' which can compel us in isolation from all the other forms of thinking and reflection with which we engage. Obedience to the kind of command God issues to Abraham is possible only because of the development of the subjectivity of the individual concerned and is itself entangled with a belief that the extreme unethical act will not be necessary, even at the last moment of holding the knife to Isaac. Ethics only has force in so far as it aids the integration of the self round the absolute aspect of the self, which is not a metaphysical structure, but a constant issue of living, thinking, and writing.

In his writing on tragedy, Kierkegaard argued that the tragedy of the moderns is more concerned with inner reflection than the tragedy of the ancients, but in ways which combine the breakdown of the ancient polis and the emergence of Christianity. To some degree these are overlapping processes, but Kierkegaard is not just concerned with the religious transformation in which the political community loses some forms of primacy, but the historical loss of the city state. This topic and others in Kierkegaard's political thought are explored in Kierkegaard on Politics (Stocker 2014). There is no suggestion that tragedy is embedded in a world of automatic unreflective adherence to communal standards. Kierkegaard' attitude to the Agamemnon sacrifice of Iphigenia is not that it cannot be criticised in the terms of the world within which Agamemnon lives, but that it is comprehensible in terms of the world in which he lives. The passage Williams quotes maybe does look like an endorsement of the first option rather than the second option, but that short passage is hardly enough for a full evaluation of Kierkegaard's position.

In general Kierkegaard's contribution to ethics can be considered to be in line with some basic considerations of Williams in Ethics and the Limits of Philosophy

Some kinds of utilitarian thought have supposed that the best results would follow if people did not think in moral terms at all, and merely (for instance) acted selfishly. With less faith in the invisible hand, others give moral considerations some priority, and some of them, as we have seen, take a highly conscientious line. But for any utilitarian it should always be an empirical question: What are the implications for deliberation of welfare's being important? In this respect, however, there are many utilitarians who belong to the morality system first and are utilitarians second. 
At the other extreme, the purest Kantian view locates the importance of morality in the importance of morality itself. What is important is that people should give moral considerations the highest deliberative priority. (Williams 1993a, 184).

As Williams notes immediately after the quoted passage, Hegel criticised both these positions to which we can add that Kierkegaard inherited those criticisms, while also revising and transforming them. A part of Kierkegaard's self-presentation is as the anti-Hegel, as the enemy of his philosophical system, as can be seen from some of the titles of his books with Concluding Unscientific Postscript as the most obvious example. Either/ Or, Philosophical Fragments, and Repetition are all anti-Hegelian titles as is the subtitle of Fear and Trembling, Dialectic Lyric. Either/or suggests a kind of alternation between positions not accommodated in Hegel's way of taking up different positions as reconciled at a more universal level. Philosophical fragments suggests something very different from a science, encyclopaedia, or general phenomenology of spirit, consciousness, or knowledge. Repetition alludes to a goal of a transcendental repetition of a subjective experience, which is to be taken as something very different to the way that Hegel suggests subjective experience and concepts are caught up in universality. Dialectical lyric suggests a combination foreign to Hegel's conception of dialectic as transcendental movement of concepts.

The differences with Hegel are not a complete rejection. Kierkegaard's first extended philosophical work, his Master's dissertation (in fact the equivalent of a doctorate) The Concept of Irony (1989), to some degree takes Hegel's side against the most subjectivist forms of Romantic Irony in ethics and literature. Kierkegaard still giving a more positive role to the aesthetic literary status of the novel, in arguments that have origins in the Romantic Ironists, so that overall he has a balance between Hegelian substance, and Romantic ironisation. Williams summarises the dangers of the former positions as "[t]he notion that people may have "real interests" different from the interests they think they have" (Williams 1993a, 40). Williams summarises the danger of the latter position, taking Richard Rorty as the target, 'in insisting, as opposed to that, on orr talking of what it is convenient to say, he is trying to reoccupy the transcendental standpoint outside human speech and activity, which is precisely what he wants us to renounce' (Williams 1993a, 138).

Kierkegaard's distance from a utilitarian point of view, can be partly understood in terms of his distance from any way of thinking building 
up from isolated moments of sensation, as the subjectivism of Romantic irony tends to. It can also be seen in Kierkegaard's account of Danish political culture in A Literary Review, which refers to decline of passion in unfavourable terms (Kierkegaard 1978,94). This is not detailed criticism of utilitarianism, which Kierkegaard never takes an object of direct criticism, presumably because utilitarian philosophy had not made much impact in Denmark. Of course a utilitarian moral philosopher might complain that these remarks in Kierkegaard only target a parody, but in any case it is just not the language of someone with utilitarian leanings and indeed no one tries to take Kierkegaard as a utilitarian. The criticisms of Kantian morality is clear in the criticism of moral universalism in Fear and Trembling (1983), particularly in 'Problema II'. Some Kierkegaard commentators argue that Fear and Trembling is essentially about religion, is 'anagogical' as Lippitt argues in Kierkegaard and Fear and Trembling (2003, 202), suggesting that the focus should be understood to be on the Abraham and Isaac story as a foreshadowing of the crucifixion. Whatever the proper overall focus of the book is, it presents certain ways of thinking about morality as unable to encompass a religious perspective, including the standard view of Kant's ethics, so that it must be presumed that there are ways of thinking about ethics better able to incorporate a religious (absolute) perspective and that Fear and Trembling has a few indications in that area. It is important to recognise that at the very least Fear and Trembling is a contribution to ethical theory in that respect.

It is not in itself controversial to distinguish Kierkegaard from Kant with regard to morality, at least with regard to the version of Kant presumed by Williams, which is the most generally accepted version. Though there are arguments for Kierkegaard's closeness to Kant, as in Green's Kierkegaard and Kant: The Hidden Debt (1992), these are most convincing in regard to the role of virtue, moral character and theology in Kant rather than general moral reasoning (Fremstedal 2014) .

Where some Kierkegaard commentators most obviously take Kierkegaard away from the kind of position Williams argues for in Ethics and the Limits of Philosophy are in claims that Kierkegaard should be seen as very communitarian in ethical thinking, in ways which might link him with Aristotle, or Hegel, or among more recent thinkers Alasdair MacIntyre (Davenport and Rudd, 2001). Williams of course distances himself from a MacIntyre style belief in fulfilled traditional community (Williams 1993a, 163 and 220 fn7). The attempt to put Kierkegaard in a communitarian perspective, particularly as posited by MacIntyre is valuable in that 
Kierkegaard should not be seen as a thinker only concerned with the individual, as isolated from community and the importance of interaction with other members of the human community. Kierkegaard certainly had a belief in the benefits of the forms of community to be found in the ancient world, in protecting the individual from the trauma of an individuality completely exposed before the undifferentiated expanse of bare sociality, a theme developed in 'The Tragic in Ancient Drama Reflected in the Tragic in Modern Drama' section of Either/Or (1987) Part I. However, beyond this the communitarian interpretation is misguided in the way it takes these aspects of Kierkegaard as just a validation of community. It tends to rely not on the discussion of antiquity, which would lead to the difficulty very quickly that Kierkegaard is referring to a pre-Christian and pagan world, but more on a very one-sided reading of Either/Or (1987) Part II, which is mostly a concerned with ethics of a kind that is criticised for not being properly compatible with a religious perspective, as contrasted with the aesthetics presented in Either/Or (1987) Part I, and in contrast with the religion presented at the very end of Part II in the 'Ultimatum'. It is a mistake to think the ethics in Either/Or (1987) is a higher stage than the aesthetic in any sense which suggests eradication and certainly a mistake to overlook the tension between the ethics of Judge Williams and the religion of 'Ulimatum'. The most obvious problem with the communitarian reading of Kierkegaard is the downplaying, if not complete blanking, of the difference between the 'religion' and the 'ethics' in Either/Or (1987), along with what Kierkegaard finds valuable in the aesthetic.

What the communitarian reading of Kierkegaard does is to take the perspective of William the Judge (or Assessor) in Either/Or (1987) Part II, as a reliable point of view with regard both to his account of ethics in terms that are communitarian in ways implicitly referring to Aristotle and Hegel, and to his account of his own personal life as an ethical model. On the latter issue, he presentation of his marriage as ethically ideal is open to question, as has been explored by Amy Laura Hall in chapter four 'The married man as master thief in Either/Or', from Kierkegaard and the Treachery of Love (Hall 2002). William's appearances in both Either/Or (1987) and Stages on Life's Way (1988) present him as a model ethically admirable husband first in his own words (Either/Or, 1987) and then through an observer (the of “"In Vino Veritas"' in Stages on Life's Way, 1988), and then again in his own prolix preaching ('Some Reflections on Marriage in Answer to Objections by a Married Man' in Stages on Life's Way, 1988). In all cases there is an unpleasant if well disguised undertone with regard to recognition of his 
wife's individuality, along with a good deal of self-satisfaction and related complacency about how far the social world is based on the best ethics and individual virtue. His wife also seems oddly fascinated by the young man William addresses in the two very long letters of complacent Polonious style advice ('The Esthetic Validity of Marriage' and 'The Balance between the Esthetic and the Ethical in the Development of the Personality') that make up the 'ethics' section of Either/Or (1987).

The young man appears to be the aesthete of Either/Or (1987) Part I and is possibly the narrator of The Diary of a Seducer, though whether that text should be taken as authored by the main voice of Either/Or (1987) Part I is itself uncertain. In any case, there is a hint of a fascination with an individuality more self-questioning and at odds with the society than the ever satisfied and self-satisfied administrator of state law. What the 'Ultimatum', the final part of Either/Or (1987), suggests is that the highest value to be pursued is that of an unconditional love for God, whatever God does. This text is sent by William to his correspondent, but it does not seem to have affected his life, though the idea of life transformed by faith and the rejection of complacency is at its heart. What the 'aesthetic' essays in Either/Or (1987) Part I suggest is that developing the kind of individuality necessary for 'religion' requires a full awareness of the tragic, the melancholic, the humorous, the erotic, the artistic, and the ironic aspect of subjectivity, all major aspects of the kind of subjectivity apparent in literary production, experiencing its own relation with itself, with community and and universality, with the absolute and the possibility of the transcendence of time.

Kierkegaard's more directly 'religious' texts are still often concerned with religion in ways that are more about a deepening of the experience of the individual's subjectivity than adherence to any set of religious dogmas, or associated moral obligations, or at least make the issues of individual existence the way into religion and inseparable from questions of faith. Works of Love (1995) provides an extensive example of this approach. It certainly distance itself from Aristotle and he Aristotelian remarks of William in Either/Or (1987) Part I in suggesting the importance of challenges to habit (Kierkegaard 1995, 36) for example, or the status of love for the neighbour (i.e. any individual human) above that of the inherently more selective friendship relation which has the highest status in Aristotle's account of ethical value. The injunction 'love your neighbour as yourself' is discussed with the emphasis on the capacity within yourself needed to make this really meaningful. It is only meaningful when the 
possibilities of the individual who loves and loves the self are realised. That leads to concerns with self-sacrifice that are not obviously close to Williams' positive concerns, but it still all refers to a way of living that strengthens individuality.

The one who loves, the one who truly loves, does not hope because eternity authenticates it to him, but he hopes because he is one who loves, and he thanks eternity that he dares to hope. In this way he brings about the best gift, better than congratulations on the best of luck, better than any human help in the worst of luck, because hope, the possibility of good, is eternity's help. (Kierkegaard 1995, 259).

The relation with eternity in love is premised on a capacity for love, to offer a gift, which includes a self-relation in love. Hope includes gratitude to eternity, but comes from the capacity of the individual to love, which itself rests on the grasp of the absolute aspect of self. The absoluteness of the self and its self-relation can only be fully grasped with regard to aesthetic accounts of tragedy and melancholy, as demonstrated in Either/ Or (1987) Part I. What love and hope do not rest on is a basic assumption of moral obligation to some duty creating God. It is possible to summarise the end result of Kierkegaard's religious writing as accepting obligation to God, but we would not have much of an understanding of any stage of Kierkegaard's arguments about subjectivity, aesthetics, psychology, ethics, religion, or anything, if we just start there. The idea of accounting for human psychology is embedded in Kierkegaard's understanding of the ethical and the religious as rooted in subjectivity, something apparent in the subtitle of The Concept of Anxiety (1980), 'A simple psychologically orientating deliberation on the dogmatic issue of hereditary sin'.

The relation between Kierkegaard's ethics and Williams' program in Ethics and the Limits of Philosophy (1993a) is not one of a simply identity, continuity, or harmony. The reasons for thinking of Kierkegaard as an important predecessor to Williams are just as much to do with the way that Kierkegaard's thought challenges Williams' thought, as with the ways in which there are agreement. That is a challenge which is not a rejection, but a call to accommodate a rich way of understanding ethical life. It is not the ethical life that Williams advocates, but since he endorses a Mill style wish for experimentation in ethical life (Williams 1993a, 172), the sort of approach continued by Robert Nozick in the 'utopia' section of 
Anarchy, State, and Utopia (1974), or by Foucault in his accounts of styles of living in various places including The Courage of Truth (2011), Lecture Eight, he must place value on religiously inspired experiments in living. An interest of some kind in religious experiments in ethics must apply in the case of Kierkegaard, where the religious life is detached from state enforcement of religion and any politicisation of religion. Williams' kind of ethics is that where there is no peculiar moral institution, but rather a concern with various kinds of arguments with practical consequences in life, a kind of pluralised less rationalistic and deterministic version of Aristotelian phronesis. Kierkegaard should play a major part in that kind of ethics given the abundant and prolific nature of his accounts of ways of living, including his thoughts on the aesthetic and religious attitudes, art forms, ways of writing, psychology, the will, politics, culture, and so on. His life was an experiment in living, a life of the write and in communication of philosophical and religious arguments though varied means each of which can be regarded as an experiment. Kierkegaard does not advocate an ethics of plural experimentation, but his life and work is a fascinating experiment, in which the work often takes full account of the plurality of valuable human experience, if certainly ordered into a hierarchy.

Barry Stocker, İstanbul Teknik Üniversitesi, Türkiye

\section{References}

Butler, Judith (2000). Antigone's Claim: Kinship Between Life and Death. New York NY: Columbia University Press.

Evans, C. Stephen (2004). Kierkegaard's Ethic of Love: Divine Commands and Moral Obligations. Oxford: Oxford University Press.

Davenport, John J. and Anthony Rudd (Eds.) (2001). Kierkegaard After MacIntryre. Peru IL: Open Court/Carus.

Foucault, Michel (2011). The Courage of Truth. (Graham Burchell, trans). Basingstoke: Palgrave Macmillan.

Fremstedal, Rone (2014). Kierkegaard and Kant on Radical Evil and the Highest Good: Virtue, Happiness, and the Kingdom of God. Basingstoke: Palgrave Macmillan.

Green, Ronald Michael (1992). Kierkegaard and Kant: The Hidden Debt. Albany NY: State University of New York Press.

Hall, Amy Laura (2002). Kierkegaard and the Treachery of Love. Cambridge: Cambridge University Press.

Hegel, G.W.F. (1977). Phenomenology of Spirit. (A.V. Miller trans.) Oxford: Oxford University Press.

Honig, Bonne (2008). 'The Other is Dead: Mourning, Justice, and the Politics of Burial'. Triquarterly Review, 131, 89-111.

Honig, Bonne (2009). 'Antigone's Laments, Creon's Grief: Mourning, Membership, 
and the Politics of Exception'. Political Theory 37(1), 5-43.

Honig, Bonnie (2010). 'Antigone's Two Laws: Greek Tragedy and the Politics of Humanism'. New Literary History, 41(1), 1-38.

Honig, Bonnie (2011). 'Ismene's Forced Choice: Sacrifice and Sorority in Sophocles' Antigone'. Arethusa, 44, 29-68.

Hume, David (1975). Enquiries Concerning Human Understanding and Concerning The Principles of Morals. Ed. P.H. Nidditch. Oxford: Oxford University Press.

Kant, Immanuel (1996). Religion within the boundaries of mere reason. (George di Giovanni trans.) in Allen W. Wood and George di Giovanni (Eds.) Religion and Rational Theology. Cambridge: Cambridge University Press.

Kierkegaard, Søren (1978). Two Ages. Howard V. Hong and Edna H. Hong (Eds.). (Howard V. Hong and Edna H. Hong. trans.). Princeton NJ: Princeton University Press.

Kierkegaard, Søren (1980). The Concept of Anxiety. Howard V. Hong and Edna H. Hong (Eds.). (Howard V. Hong and Edna H. Hong. trans.). Princeton NJ: Princeton University Press.

Kierkegaard, Søren (1983). Fear and Trembling/Repetition. Howard V. Hong and Edna H. Hong (Eds.). (Howard V. Hong and Edna H. Hong. trans.). Princeton NJ: Princeton University Press.

Kierkegaard, Søren (1987). Either/Or (two volumes) Howard V. Hong and Edna H. Hong (Eds.). (Howard V. Hong and Edna H. Hong. trans.). Princeton NJ: Princeton University Press.

Kierkegaard, Søren (1988). Stages on Life's Way. Howard V. Hong and Edna H. Hong (Eds.). (Howard V. Hong and Edna H. Hong. trans.). Princeton NJ: Princeton University Press.

Kierkegaard, Søren (1989). The Concept of Irony/Notes on Schelling's Berlin Lectures Howard V. Hong and Edna H. Hong (Eds.). (Howard V. Hong and Edna H. Hong. trans.). Princeton NJ: Princeton University Press.

Kierkegaard, Søren (1989). The Concept of Irony. Howard V. Hong and Edna H. Hong (Eds.). (Howard V. Hong and Edna H. Hong. trans.). Princeton NJ: Princeton University Press.

Kierkegaard, Søren (1992). Concluding Unscientific Postscript to Philosophical Fragments. Howard V. Hong and Edna H. Hong (Eds.). (Howard V. Hong and Edna H. Hong. trans.). Princeton NJ: Princeton University Press.

Kierkegaard, Søren (1995). Works of Love. Howard V. Hong and Edna H. Hong (Eds.). (Howard V. Hong and Edna H. Hong. trans.). Princeton NJ: Princeton University Press.

Manis, R. Zachary (2009). 'Kierkegaard and divine-command theory: Replies to Quinn and Evans'. Religious Studies, 45, 289-307.

Nozick, Robert (1974). Anarchy, State, and Utopia. Oxford: Blackwell, 1974.

Quinn, Philip L. (1998). 'Kierkegaard's Christian Ethics' in Alastair Hannay and Gordon D. Marino (eds.) The Cambridge Companion to Kierkegaard. Cambridge: Cambridge University Press.

Schelling, F.W.J.(2006). Philosophical Investigations into the Essence of Human Freedom. (Jeff Love and Johannes Schmidt trans.). Albany NY: State University of New York Press.

Stocker, Barry (2014). Kierkegaard on Politics. Basingstoke: Palgrave Macmillan. Williams, Bernard (1972). Morality: An Introduction to Ethics. Cambridge: Cambridge University Press. 
Williams, Bernard (1981). Moral Luck: Philosophical Papers 1973-1980. Cambridge: Cambridge University Press.

Williams, Bernard (1993a). Ethics and the Limits of Philosophy [amended edition]. London: Fontana Press [first published 1985].

Williams, Bernard (1993b). Shame and Necessity. Berkeley CA: University of California Press. 